\title{
Student dropout in primary and secondary education in the Republic of Serbia ${ }^{1}$
}

\author{
Ksenija Krstić2 \\ University of Belgrade, Faculty of Philosophy
}

\section{Ivana Stepanović Ilić}

University of Belgrade, Faculty of Philosophy, Institute of Psychology

\author{
Marina Videnović \\ University of Belgrade, Faculty of Philosophy, Institute of Psychology
}

\begin{abstract}
Student dropout from school is a serious problem in educational systems all over the world. This paper will provide an overview of the various dropout definitions and their consequences for measuring and monitoring. Since a diversity of factors (individual, familial, school and systematic) is connected with student attrition in foreign resear$\mathrm{ch}$, the attempt has been made to systematise their results and provide data regarding similar Serbian studies. Considering the fact that there are no systematic analyses of students' dropout rate in Serbia, the existing data from primary and secondary schools from a variety of statistical sources will be presented. We conclude that one way to reduce dropout in Serbia is to further develop research interest in the topic, as well as the strategies for monitoring, prevention and intervention.
\end{abstract}

Key words: dropout, dropout factors, dropout indicators, dropout rates in Serbia

Student dropout from school is an important issue, visible through two indicators. Firstly, in the last 50 years there has been a significant rise in the number of academic papers addressing this issue. The EBSCO search engine

1 The paper is the product of work on the Project "Identification, measurement and development of cognitive and emotional competences important for a society oriented towards European integrations" (No. 179018), conducted by the Institute of Psychology, Faculty of Philosophy University of Belgrade, and funded by the Ministry of Education, Science and Technological Development, Republic of Serbia, and on the Project "Research and analysis study of school, individual and social factors influencing primary and secondary school drop-out and identification of innovative approaches for dropout prevention in school and through community services" funded by UNICEF.

2 kkrstic@f.bg.ac.rs 
for academic papers provides about 40 results for the key words "dropout" and "education" in the period 1960-70, and around 600 for the following decade. In the last decade of the $20^{\text {th }}$ century, the number already reached 1,900 , while in the period between 2000 and today it has even exceeded 8,500 , with one half published only in the last five years!

Secondly, the significance of the dropout problem is further emphasised by the fact that the majority of European countries, as well as the USA and Canada, listed a decrease in student dropout as one of their educational objectives. In the "No Child Left Behind" Act (2001), the USA set as the goal the secondary education completion rate of $90 \%$. Similarly, in its "Lisbon 2000" Strategy and "Europe 2020" Strategy, the European Union quoted as one of its five key objectives a decrease in student dropout rate to under 10\% (EUROPE 2020, 2010; Lisbon, 2000). The Strategy for the development of education in Serbia until 2020 includes an increase of the percentage of the population engaged in compulsory primary education, and a reduction of the dropout rate from primary education to $5 \%$, not only at the national level, but also among vulnerable groups (the children from rural areas, poor Roma children, disabled children and those with special educational needs). Although secondary education is still not compulsory in Serbia at this moment, the Strategy for the development of education also predicts a rise in the percentage of population engaged in secondary education (Strategija razvoja obrazovanja u Srbiji do 2020. godine, 2012). Therefore, one of the ways of improving the educational system in Serbia is a reduction in student dropout and early school leaving within the educational system.

\section{The definition of student dropout}

The term dropout refers to children who abandon the educational system without completing the academic year they started, i.e. to those who did not obtain the right to get the final mark for that academic year and to be issued an official document to prove they finished the particular year of primary or secondary school (Estevao \& Alvares, 2014; Suh et al., 2007). In different countries, and in the literature, this term is defined in different ways (De Witte et al., 2013; Rumberger, 1987). Generally speaking, there are two types of dropout definitions: the formal and the functional ones (Estevao \& Alvares, 2014).

In formal definitions, dropping out refers to termination of compulsory education and it is defined as leaving school before completing it (GHK, 2005; Nesse, 2010). The advantage of such definitions lies in the existence of a unique, simply defined and easily measurable criterion and the fact that they clearly indicate the objective of compensatory measures: to return students into the educational system and make them complete compulsory education. 
However, their flaw is that they generate measures and data not mutually comparable in different countries, where compulsory education thresholds are defined in different ways (Nesse, 2010).

On the other hand, functional definitions take into consideration the consequences of dropping out of school, namely, whether an individual has obtained a certain level of qualifications required for a successful social and professional life. According to these definitions, dropping out is perceived as termination of schooling before qualifying for the ISCED 3c diploma (UNESCO, 1997) or before obtaining the qualifications required for accessing a wider range of opportunities within the job market. These definitions emphasise employment opportunities and professional abilities determined by an individual's level of education (Estevao \& Alvares, 2014; Nesse, 2010). Still, they do not include the students who drop out of school because they have to find or have an opportunity to find a job (Nesse, 2010).

Furthermore, there is a confusion of terms in the literature regarding insufficient differentiation and parallel use of similar terms. The following terms are often used in the same text: dropout, attrition, withdrawal, early school leaving, student elimination (De Witte et al., 2013). These terms are mostly deemed synonymous, but, as an example, we shall briefly analyse the term early school leaving and its relation with the term dropout.

Early school leaving was defined in 1999 as one of the key indicators of the European Union for monitoring educational outcomes and fulfilling the aims of the EU educational strategy for 2020 (Estevao \& Alvares, 2014; EUROSTAT, 2005). According to the EU definition, the term early school leaving, or, more precisely, early school and training leaving refers to persons aged 18 to 24 who have not completed at least a three-year secondary school (ISCED 3c) or obtained a public document proving the completion of at least a three-year secondary school (UNESCO, 1997). Comparing these definitions, we can draw attention to the similarities and differences between the terms in question. Both student dropout from the educational system and early school leaving refer to children dropping out of school without obtaining a diploma of completed education. Dropping out of school in the narrowest sense means that a student who started a particular year of education at the beginning of an academic year did not complete it at the end of the academic year. A student can be officially enrolled in school, but if his/ her absence goes over the legally defined maximum (usually around a third of the overall lessons), he/she will be considered as a dropout. Still, the term student dropout is not limited to a particular age. Hence, dropout will include students who left primary school at the age of 12 to 14, without completing the year they enrolled that particular academic year, even though they will not be classified as early school leavers as they do not belong to the group of 18-24 year-olds. Such students have an option to return to school in the next 
few years or enrol in and complete another form of education or training outside of school and achieve qualification at the ISCED3 level. If in that time the student does not continue and finish at least a three-year secondary school, he/she can be considered as an early school leaver. On the other hand, if a student completes primary but does not follow with secondary education (which is not compulsory in Serbia), they will not fall into the student dropout category of those who have not completed a particular year of education, but since they will not have a diploma at the ISCED3 level, such students aged 18 will be labelled as early school leavers. Bearing all this in mind, this article addresses the student dropout phenomenon as dropping out of primary or secondary school before the age of 18 .

Different definitions of dropout lead to different indicators and measures for monitoring this phenomenon (Estevao \& Alvares, 2014; GHK, 2005; Rumberger, 1987), which decreases comparability, reliability and validity of data regarding student dropout (O’Brennan \& McNeely, 2008). A particular problem related to measuring and monitoring student dropout and early school leaving is connected to the possibility for students to be enrolled in some form of education/training not providing recognised qualifications, so they would be statistically classified as the persons who dropped out of school even though they "are in school", i.e. included in some educational programme or training. These conceptual difficulties, however, do not diminish the significance of analysing and monitoring this problem.

\section{Monitoring of dropping out of educational system}

Previously mentioned differences in the concept and definition of student dropout and early school leaving are also reflected on the differences in determining indicators for measuring and monitoring of this phenomenon. Starting from the narrowest definition, dropout can be operationalised as the difference between the number of students who started the academic year and the number of students who finished it. The established difference signifies the number of students who dropped out of school in the course of that particular academic year. However, the number also includes the children who dropped out of one school but continued their education in another, switched to external or some other form of education and so on. Besides, the student can, after a while, return and finish school, which means that the obtained dropout rate is exaggerated.

In EU countries, the most frequently used EUROSTAT indicator of early school leaving is determined by three conditions: it refers to individuals aged between 18 and 24 who at most have an ISCED 2 diploma (up to two years of secondary school), and do not attend a school, training or professional development programme (in the last 4 weeks before completing the questionnaire on workforce). The same criteria are used in the OECD 
indicator of early school leaving, but they refer to the older population, aged 20 to 24 . This difference in otherwise similar operationalisations of early school leaving prevents the comparison between the data obtained in these different frameworks. Both stated indicators belong to "status" indicators, which means that they provide the percentage of early school leaving at a particular moment in time, according to the predefined criteria (GHK, 2005). Apart from the problems related to the way of collecting these data (Estevao \& Alvares, 2014; GHK, 2005), these indicators have their own conceptual limitations. The indicators defined in such a way represent cumulative and retrospective measures for dropping out of school because they do not provide data on the students who dropped out of school in the course of one year, but a cumulative percentage of children without certain qualifications at the age of 18 (Estevao \& Alvares, 2014; Nesse, 2010). Furthermore, these data do not provide information about the level of education the children completed, i.e. how many of them terminated their education during or after primary school, and how many after one or two years of secondary education.

Three types of dropout indicators have been singled out in the USA. The first one, the status dropout rate, represents a cumulative rate that shows the ratio of people aged 16 to 24 who dropped out of school (have not enrolled or have no secondary school diploma or its equivalent) in general population, irrespective of when they dropped out of school (dropout prevalence). The second indicator, the event dropout rate, is connected with the number of new students who dropped out of school in the previous school year (dropout incidence). More precisely, this indicator is related to the students aged between 15 and 24 who dropped out of the $10^{\text {th }}$ and $12^{\text {th }}$ years in the previous school year. The third indicator, the cohort dropout rate, is to do with the dropout rate in a particular group of students, e.g. in a particular age or minority group.

In Serbia, The National Education Council (NPS) defined a proposal of indicators for monitoring the state of affairs in education (Nacionalni prosvetni savet, 2011). One category of indicators contains a group of 42 indicators related to the percentage of population engaged in schooling, student progress and completion within primary, secondary and tertiary education. The list includes indicators pointing at:

- the percentage of children and the young engaged in different levels of education - the number of children enrolled in a particular level of education (pre-school, primary or secondary) compared to the overall number of children of a particular age group;

- regularity of student progress in primary and secondary school - the number of children who have not repeated a single year since they began a particular level of education (primary or secondary school) compared to the overall number of children enrolled in that particular level of education (primary or secondary); 
- the rate of repeating a year in primary and secondary schools - the ratio of the number of students enrolled in the same year of education as in the previous academic year and the overall number of students enrolled in primary or secondary schools;

- dropout rate at different levels of education - the difference in the number of students at the beginning and the number of students at the end of the school year, compared to the number of students enrolled at the beginning of a particular academic year;

- completion rate at a particular level of education - the number of students who completed an academic year compared to the number of students who enrolled;

- the rate of transfer from primary to secondary education ${ }^{3}$ or the rate of continuation of education after primary school represents the number of students who started the first year of secondary school (regardless of the type of secondary school) compared to the number of students who started the final year of primary education in the previous academic year.

\section{Causes of student dropout}

A substantial amount of research has been dedicated to establishing the causes leading to dropping out of school and the majority of them indicate that there is not a single factor, but rather a combination of factors (Janosz et al., 2000; Lamot et al., 2013; Lyche, 2010; Rumberger, 2011). Based on vast empirical material, we can conclude that not all the students who drop out of school are the same (Janosz et al., 1997; Rumberger, 1987), and that dropout is usually a consequence of a combination of factors whose impact can be realised via different routes (De Witte et al., 2013; Janosz et al., 2000; Jimerson et al., 2000; Rumberger, 2011).

Usually, several groups of factors are identified: individual, familial, school and others, referred to as social, community or systemic, depending on the particular research focus. Dropout factors are so intertwined that it is extremely difficult to separate them both theoretically and empirically, which resulted in various classifications, with different, often overlapping terms. Consequently, our classification does not pretend to solve these issues but to demonstrate the diversity of factors whose connections with student dropout have been empirically examined. We will also provide the findings of Serbian studies, although their number is very small, especially in the field of scientific research of dropout risks.

3 Apart from the listed ones, this category also includes the indicators showing the guidance of children outside the schools within compulsory education, the inclusiveness of compulsory education and the participation of adults in lifelong education. 


\section{Individual factors}

A variety of students' characteristics have been associated with dropout. One group, classified as academic factors, is related to students' academic achievement, motivation for learning, educational aspirations, and involvement in school activities. Academic achievement is stressed as one of the most common and important factors (Lyche, 2010; Rumberger \& Lin, 2008), expressed by standardised or school tests, an average mark, reading and mathematical literacy, and sometimes through individual syllabi and additional lessons. Students with higher achievement are less likely to leave school (Allensworth, 2005; Dalton et al., 2009; Dustmann \& van Soest, 2008; Entwisle et al., 2004; Rumberger, 2004). However, there are studies which do not indicate a correlation between academic achievement and dropping out of school. More precisely, their authors believe that students' academic achievement is not directly related to dropout, but has an indirect effect (Allensworth, 2005; Entwisle et al., 2004).

Very important predictors of dropping out of compulsory education are long absences from school and repeating a year. Truancy is the first sign of dropout risk and one of the indicators of low motivation for learning and schooling (Balfanz et al., 2007; Hidi \& Harackiewicz, 2000; Legault et al., 2006; MacIver \& MacIver, 2009). Numerous studies have shown that repeating a year, which is accompanied by the feeling of failure, falling behind and students' evaluation that they are not capable enough, significantly increases the risk of dropping out of school permanently (Allensworth, 2005; Entwisle et al., 2004; Lyche, 2010; Plank et al., 2005; Rumberger, 2004). Other factors that also enhance dropout risk, such as pregnancy or finding a job, are more common in older students.

Another group of common risk factors includes low motivation, educational expectations, as well as low participation in school and extracurricular activities (De Witte et al., 2013; Lyche, 2010). One US study established that only $35 \%$ of students dropped out of school due to failure, whilst $69 \%$ stated lack of motivation as the main reason (Bridgeland et al., 2006). Student engagement in various curricular and extracurricular activities (taking place in school), participation in decision making and organisation of school life, respecting school regulations and norms, as well as inclusion in positive interaction with teachers and students, represent relevant indicators of students' general inclusion and the feeling of belonging to the school, which are related to successful education completing (Newman et al., 1992; Nield et al., 2008; Wang \& Fredricks, 2014).

The specific factor group is related to risky behaviours during spare time as well as aggressiveness and discipline problems within school (Cairns et al., 1989; Garnier et al., 1997; Milas, Ferić \& Šakić, 2010; Rumberger \& Lim, 2008). Research indicates that students from poor and/or dysfunctional 
families, belonging to anti-social peer groups are highly likely to drop out of school even if they have no learning problems (Battin-Pearson et al., 2000; Janosz et al., 1997; Rumberger \& Lim, 2008).

A special group of individual factors is connected to demographic variables such as gender, race and ethnicity. The literature suggests that these factors are almost always connected with other individual (students' educational motivation and engagement) or school (school values, teacher expectations) factors (Cataldi et al., 2009; Dalton et al., 2009; DesJardins et al., 2006; Entwisle et al., 2005; Kaufman et al., 2004; Plank et al., 2005). The children from marginalised groups are especially affected by the complex interaction of individual, school and social factors specifically related to their background. They often live in undeveloped areas which, together with language barriers, cultural differences, frequent relocating and exposure to prejudice, additionally contributes to high dropout rate (Bowers \& Sprott, 2012; Bynum \& Thompson, 1983; Rumberger, 2011).

Serbian sources regarding the individual factors contribution are very rare. One recent study combining the quantitative and qualitative approach isolated the following influences: learning difficulties, low learning motivation, impulsiveness personality trait and behavioural problems, such as fighting, theft or substance abuse (Lazarević et al., 2014a). However, several project reports are dedicated to a sensitive position of Roma children and their schooling difficulties, influenced, as already mentioned, by the interaction of individual and other dropout factors (Centar za obrazovne politike, 2013; Open Society Institute, 2010).

\section{Familial factors}

Among familial risk factors, the following are often listed: family size and structure, socio-economic status, the presence of toys and contents stimulating learning, parental practices towards education (learning support and monitoring) and their level of education (Cooper et al., 2005; Entwisle et al., 2004; Kalmijn \& Kraaykamp, 2003; Plank et al., 2005; Rumberger, 1983; 2004). Children are more likely to drop out of school if their family SES is lower (Dalton et al., 2009; Lyche, 2010; Orthner et al., 2003; Ou \& Reynolds, 2006; Rumberger \& Lim, 2008). The studies in the USA, UK and Australia have shown that one of the common reasons for dropping out of school is the youngsters' need to support their family or a desire to get a job and earn money (Bridgeland et al., 2006; Lamb et al., 2004). Research studies in several countries have indicated that poor families which are also dysfunctional (with domestic violence, abuse, alcoholism) more often have children who drop out of school (Lamb et al., 2004). The low level of parents' education (at least one parent did not finish secondary school), negative attitude towards 
education and placing low value on education significantly increase the risk of children attrition (Bertrand, 1962; Dunn et al., 2004; Lyche, 2010). Two studies show that each year of parents' education decreases children's dropout likelihood (Ingrum, 2006; Traag \& van der Velden, 2008). Insufficient parents' engagement in child's schooling and parents' or elder siblings' history of dropping out of school significantly increase the risk of other children becoming early school leavers as well (Bridgeland et al., 2006; Rumberger \& Lim, 2008). Still, it should be emphasised that although they are at a greater risk, it is not just the children from poor and ethnic minority families who drop out of school. Children from all socio-economic and cultural groups drop out of school (Janosz et al., 2000; Rumberger, 1987).

Serbian projects and research on dropout often consider family characteristics as a factor contributing to attrition (Centar za obrazovne politike, 2013; Lazarević et al., 2014b). One research (Lazarević et al., 2014b; Videnović \& Lazarević, 2017), dealing with case studies of children who left school and their parents, listed the following family features as important: family structure, relations and atmosphere, socio-economic status, parental educational level, (non)existence of cultural tools within the family that support children's intellectual development and education, valuation of education by the family and children, and parents' educational aspirations. The authors particularly emphasise that the structure of the families of early school leavers is often incomplete (because of the separation or parents death) and that different kinds of dysfunctions are present.

\section{School factors}

A group of factors regarding school characteristics includes numerous and innately different factors: school size and type, variety of courses, school resources, number of staff, school equipment, and so on. The findings about the significance of these factors are inconsistent (De Witte et al., 2013). The schools with a better selection of students exhibit a lower rate of student dropout compared to the schools available to a larger number of students, which implies a greater percentage of children from poor and minority communities (Dalton et al., 2009; De Witte et al., 2013; MacIver \& MacIver, 2009; Rumberger, 2004). Some studies claim that dropout is lower in smaller schools, with fewer classes and students per class, although it is hard to separate the influence of these conditions from social climate and teachers' practices, which are better and more positive in such schools (Blue \& Cook, 2004; De Witte et al., 2013; Plank et al., 2005). Even though some studies established that student structure (average SES, percentage of minority population and so on) influences dropping out of school (Lyche, 2010), more thorough analyses demonstrated that adequate teachers' practices can diminish the effect of these variables (Rumberger \& Lim, 2008). 
Apart from these, some of the most commonly listed school characteristics important for dropout are social and academic climate, teachers' practice and the quality of teaching. Numerous studies have confirmed that the attrition risk is lower if schools offer more extracurricular activities, if teachers' expectations are higher, if the quality of teaching and learning support is better, if cohesion is stronger, if students' participation in school activities is higher and if students are taught to have the feeling of belonging to the school (Blue \& Cook, 2004; De Witte et al., 2013; Hawkins et al., 2001; Rumberger, 2004). These factors lead to better social inclusion, greater feeling of belonging to the school, more positive relationships with teachers, which in turn increases the chances for students at risk of dropping out to be recognised early and given adequate support (Lyche, 2010; Newman et al., 1992; Nield et al., 2008). Positive relationships between students and teachers and positive climate in school serve as significant protective factors, particularly in schools with low students' SES (Rumberger \& Lim, 2008).

It seems that a greater number of Serbian studies dealt with school dropout factors than with the other ones. The results of COP's (2013) project show that the measures oriented towards early detection of students at risk, inclusive school climate and additional learning support for students were productive in reducing the dropout rate (Čekić Marković, Radišić, Jovanović \& Ranković, 2017). One study (Kovač Cerović et al., 2016) provided a rather interesting perspective on the significance and constructive approach, from the framework of the Activity theory, towards limitations of individual educational plans in order to increase inclusiveness of Serbian schools. The research study that investigated the schools with high dropout rate in 17 Serbian municipalities (Krstić et al., 2016; Simić \& Krstić, 2017), as well as the children who left school, has shown that the factors connected with the quality of learning and social relations within schools are associated with students' dropout. Thus, the low quality and individualisation of teaching, together with the lack of learning support (remedial classes, extracurricular activities), are accompanied with high dropout rate. Furthermore, dysfunctional teacher-student relations, the lack of motivation from both sides, the absence of emotional support for students, together with disturbed peer relationships, are highly related to dropout. Similar factors and additional specific ones are associated with schooling problems and attrition of Roma (Franceško, 2006; Rado, 2010) and children with special needs (Rajović, 2008; UNICEF, IPSOS \& Ministry of Education, Science and Technological Development RS, 2015) in Serbia.

\section{Systemic factors}

Previously reviewed dropout risk factors should be analysed in the context of the wider socio-cultural community, whose organisation, customs, norms and values have impact on single factors and their interaction as 
well (De Witte et al., 2013). The region urbanisation, job market features and schools availability are aspects often referred to as community factors influencing student dropout (Lyche, 2010; De Witte et al., 2013; Rumberger, 2004). Besides the degree of certain region's development, as even more significant are considered social factors that could reduce the dropout rate: positive education valuation in the wider community and culture, absence of prejudice and discrimination against minority groups and encouraging supportive peer networks (Blue \& Cook, 2004; Cooper et al., 2005; Entwisle et al, 2005; Herbert \& Reis, 1999; Kalmijn \& Kraaykamp, 2003; Lyche, 2010). More specifically, the authors stress the characteristics of the entire education system that influence students' dropout directly, through law regulations and policy measures, but also indirectly, by affecting the functioning of particular schools. Efficient measures against student dropout on this level are connected with early tracking of children at risk, updating databases, expanding the duration of compulsory education, providing flexible educational routes adjusted to students' individual needs as well as enabling high inclusion on each educational level (De Witte et al., 2013; European Commission/EACEA/ Eurydice/Cedefop, 2014; Hattie, 2009; Rumberger, 2011). Additionally, linking various institutions on all existing levels, from local to national, is very significant for successful dropout prevention. Rumberger (2011) insists on collective responsibility for student learning process, highlighting the importance of institutions networking, while the European Commission's report (2014) points out that cross-government cooperation is crucial for reducing students' dropout.

Similarly to considerations in foreign literature, these wider social factors are relatively often analysed but rarely investigated in Serbian studies. The undeveloped regions in Serbia also usually have the highest dropout rates. One sociological survey (Cvejić et al., 2010) found that the dropout rate in rural areas was close to $45 \%$. Systematising the dropout factors outside school and family from the ecological perspective, one recent investigation (Stepanović Ilić, Lazarević \& Simić, 2017) named the following negative ecosystem influences connected to poor regions: lack of coordination between educational profiles and shortages on the job market; lack of career guidance in schools; parents going abroad to work, which leads to discontinued education of their children. The authors dealing with the characteristics of the educational system in Serbia often stress its unfavourable features associated with dropout. The report considering education obstacles the children from vulnerable groups are facing highlighted the importance of relevant polices embedded in law regulations but also the necessity of their more efficient implementation, recommending the measures aimed at educational support and active inclusion of such students (Ministry of Education, Science and Technological Development RS, Social Inclusion and Poverty Reduction Unit 
\& UNICEF, 2014). Rado (2010) points out the Ministry of Education and governmental responsibility for a high dropout rate, emphasising the lack of databases, weak implementation capacity of the Ministry, undeveloped policy coordination mechanisms, as well as unclear and unstable educational priorities. Analysing the existing measures aimed at enabling education equity, Pešikan and Ivić (2016) concluded that present social and political conditions in Serbia make educational measures intended to increase fairness relatively mild. These authors explained the difficulties in the implementation of measures from the theoretical perspectives, treating education as a system for the reproduction of the social structure, i.e. social inequity.

\section{Existing data on dropping out from primary and secondary education in the Republic of Serbia ${ }^{4}$}

The aim of this part of the paper is to provide an overview of the existing data about the dropout rate in Serbia. The second aim is to analyse inequalities in dropout based on gender, economic status of the family and minority group affiliation.

There are several sources, documents and reports that are dedicated to this issue, but they are often used independently. Consequently, a clear answer to the question of how many students leave primary or secondary school in Serbia cannot be provided, which should serve as the first step in planning the effective intervention. The Ministry of Education, Science and Technological Development does not perform any systematic monitoring of student dropout and has not got official data on student dropout at a national or local level. From the list of indicators of dropout proposed by the National Education Council (NPS), at this moment, there are only three types of data and they will be included in this overview:

- the percentage of children from a particular school generation enrolled in primary/secondary school,

- the dropout rate, defined as the percentage of students who started one school year but did not finish it; the rate is calculated as a mean rate from primary and secondary school,

- the completion rate, defined as the percentage of students who finished primary or secondary school with their school generation.

4 Compulsory education in Serbia lasts for 9 years and is free of charge. After the first four years, the children automatically go to year five without having to fulfil any additional requirements. After the completion of primary school, children can choose to continue their education in secondary schools (grammar schools, four-year or three-year vocational schools), which are also free but not compulsory. 
These measures are calculated separately for each school year. Consequently, there are no available data about the cumulative effect of early school leaving similar and comparable to those used in the EU countries and the USA.

The data from the Statistical Office of the Republic of Serbia's (RZS) database for 2014 (RZS-DevInfo, 2016) were used as a source for the analysis as well as the following documents and reports: the Strategy for education development in Serbia 2020 (Službeni glasnik Republike Srbije, 2012), The first national report on social inclusion and poverty reduction in Serbia (Serbian Government, 2011), the Report on monitoring social inclusion in Serbia from 2012 (Tim za socijalno uključivanje i smanjenje siromaštva, 2012), The analysis of multiple indicator cluster survey data regarding the position of women and children (MICS5, 2014), the Report on activities of the National Education Council of the Republic of Serbia for 2012 (Nacionalni prosvetni savet, 2012) and the Statistical Yearbook of the Republic of Serbia Education section, from 2012 and 2015 (Republički zavod za statistiku, 2012; 2015a).

\section{Dropout from primary education}

According to RZS (Republički zavod za statistiku, 2012) data concerning the general population, the percentage of children included in primary education for the academic year 2011/2012 was 95.25\%, and for the year $2013 / 2014$ it was $97.98 \%^{5}$ (Table 1), with no significant gender differences - the gender equality index is 0.99 (MICS5, 2014). These data indicate an increase in the percentage of children included in compulsory primary education, which, although high, as we shall see, is not universal.

When analysing the data at the local level, it can be seen that the percentage of children included in primary education differs greatly between regions. In some places, it is almost universal ${ }^{6}$ but there are some municipalities with the percentage under $70 \%{ }^{7}$, and some with the percentage between 70 and $80 \%^{8}$ (RZS-DevInfo, 2016). The majority of these municipalities are amongst

5 The latest published data are those concerning educational statistics for the 2013/2014 academic year.

6 South Bačka, The Nišava, Šumadija, Raška and The Moravica districts.

7 Gadžin Han, Žagubica, Žabari, Kučevo, Vladimirci, Kladovo, Petrovac na Mlavi, Pećinci, Malo Crniće, Stara Pazova, Veliko Gradište, Golubac, Bujanovac, Preševo, Medveđa i Crna Trava.

8 Varvarin, Sjenica, Bogatić, Ub, Ćićevac, Priboj, Merošina, Prijepolje, Beograd-Zemun, Bosilegrad, Osečina, Topola, Ljubovija, Ražanj, Svilajnac, Tutin, Žitorađa, Kovin, Boljevac, Brus, Niš-Palilula, Bela Crkva, Ćuprija, Beograd - Palilula, Majdanpek, Trgovište, Inđija, Mionica, Despotovac and Negotin. 
the poorest in the country, which confirms the interrelationship between low economic development and scarce educational opportunities for children.

The percentage of children included in primary education in several municipalities is particularly lower for girls (by 5 to $9 \%$ lower) than for boys, whereas in two municipalities the percentage is $11-13 \%$ higher for girls ${ }^{9}$.

The percentage of children included in primary education is also relatively low when it comes to children from vulnerable groups. The data obtained from multiple indicator cluster surveys (MICS5) in 2014 imply that the percentage of children included in primary education is lower in Roma settlements (85\%) and for children from the poorest families (95\%). There are no reliable data on the percentage of children with special needs included in primary education.

The latest official data (RZS-DevInfo, 2016) show that the dropout rate from primary education is lower than $1 \%$ at the national level for both girls and boys (ranging from 0.4 to 0.7 for the period 2012-2014). The percentage of children who start the first year of primary education and continue through to the fifth is very high, ranging from $98.1 \%$ for 2012 to $99.8 \%$ for 2014 . However, the dropout rate in primary education is significantly higher for vulnerable groups, such as Roma students $(8.9 \%$, COP, 2013) or the children from rural areas, around $12 \%$, even reaching $20 \%$ in some municipalities (RZS-DevInfo, 2016).

According to the data from the Strategy for education development in Serbia 2020, 13 to $15 \%$ of students from one generation drop out from primary education overall (including the children who do not start and those who do not complete primary school), which is significantly higher in children from vulnerable groups. In addition, according to this document, there are around $2 \%$ of students who do not continue their education after primary school. Therefore, around $15-17 \%$ of a generation completes only primary school or a lower level of education. The difference between these data and the data provided by the RZS is impossible to explain because the details about how the results were obtained were not provided in the Strategy for education development in Serbia 2020.

The primary school completion rate at the national level for the year 2014 was $94.01 \%$ (Table 1). Lower rates were recorded in rural areas (88\%). As reported by MICS4 from $2010^{10}$, primary school completion rate is low in children from poor families $(72 \%)$, as well as in children whose mothers only completed primary education (75\%). Again, there are huge differences between the municipalities, with percentage ranges between $70 \%$ and $80 \%{ }^{11}$,

9 Source: RZS - DevInfo, 2016.

10 The data for 2014 for these indicators are not reliable enough since they are based on a sample with fewer than 25 respondents.

11 Beočin, Senta, Kučevo, Malo Crnjiće, Golubac, Kovin, Nova Crnja, Gadžin Han, Pećinci, Veliko Gradište, Bojnik, Stara Pazova, Bujanovac, Vladimirci and Negotin. 
and even under $70 \%^{12}$. According to MICS4 data from 2010, around $64 \%$ of students from Roma settlements finish eight years of primary education, but only $35 \%$ on time, with no significant gender differences.

\section{Dropout from secondary education}

Finishing primary school is not enough, having in mind that, on the $21^{\text {st }}$ century job market, a secondary school diploma has become a minimum job requirement (Kerka, 2006). A total of 278.181 students started secondary education in 2013 (90.1\%), i.e. 85.2\% of students aged 15 to 18 for the 2013/2014 academic year (RZS-DevInfo, 2016). The rate of continuation of education after primary school for 2014 was very high at the national level, about $99.8 \%$ (Table 1), and is the same for both boys and girls. For Roma population, the rate of commencing secondary school is $62.2 \%$ (MICS5, 2014).

However, the analysis of data on the percentage of children included in secondary education provides a less optimistic conclusion. At the national level, according to RZS data, the percentage of children engaged in secondary education was $90.1 \%$ in 2013 (children who did not engage or finish primary school were taken into account). As reported by MICS5 for 2014, the percentage of children engaged in secondary education was higher for girls (93\%) than for boys (86\%). The analysis of data at the regional level has revealed very noticeable differences in the percentages of children included in secondary education in various districts, with the lowest values between $60 \%$ and $70 \%$. The analysis of gender index has shown that the percentage of boys and girls is equal in most districts ${ }^{13}$. According to MICS5 data for 2014, the percentage of Roma children in secondary education was $21.6 \%$, but with a significant gender discrepancy: $14.9 \%$ of girls compared to $28 \%$ of boys attended secondary school. As reported by the same source, the net rate of secondary school attendance for children from the poorest families was 74\%.

As reported by RZS (Republički zavod za statistiku, 2015b), the secondary school completion rate for 2014 at the national level was $83.6 \%$ and it was significantly higher for girls than for boys $(86.9 \%$ and $80.5 \%$, respectively). The completion rate was highest in grammar schools, followed by four-year vocational schools, and lowest in three-year vocational schools (only 74.2\%).

According to the same source, the dropout rate for secondary schools at the national level was $1.19 \%$ for the $2013 / 2014$ academic year (Table 1). The

12 Merošina, Medveđa and Crna Trava.

13 In two districts, the percentage of boys is higher than that of girls (Bor and West Bačka districts), and in 9 districts the percentage of girls is higher than that of boys (Zlatibor, Šumadija, Braničevo, the Kolubara, Mačva, the Moravica, Toplica, Srem and Middle Banat districts). 
dropout rate was higher in three-year secondary schools (3.2\%) than in the four-year ones $(1.3 \%)$.

Table 1: The RZS data on student dropout indicators at the national level for the 2013/ 2014 school year

\begin{tabular}{|c|c|c|c|c|c|c|}
\hline & \multicolumn{2}{|c|}{ Primary education } & \multirow{2}{*}{$\begin{array}{c}\text { Rate of } \\
\text { continuation } \\
\text { of education }\end{array}$} & \multicolumn{2}{|c|}{ Secondary education* } & \multirow{2}{*}{$\begin{array}{c}\text { Rate of } \\
\text { continuation } \\
\text { of education }\end{array}$} \\
\hline & $\begin{array}{l}\text { Percentage } \\
\text { of children } \\
\text { included }\end{array}$ & $\begin{array}{l}\text { Completion } \\
\text { rate }\end{array}$ & & $\begin{array}{l}\text { Percentage } \\
\text { of children } \\
\text { included }\end{array}$ & $\begin{array}{l}\text { Completion } \\
\text { rate }\end{array}$ & \\
\hline $2013 / 2014$ & 97.98 & 94.01 & 100 & 90.1 & 83.6 & $90 \%$ \\
\hline
\end{tabular}

(Table 5.9 adapted from Statistical Yearbook of the Republic of Serbia - Education, 2015)

*Secondary education consists of grammar schools and secondary vocational schools (three-year and four-year profiles)

There are significant differences in the dropout rate in various districts and municipalities in Serbia, with the highest value of $8 \%{ }^{14}$. At the national level, the dropout rate for secondary education was higher for boys (2.2\%) than for girls $(0.6 \%)$, with noticeable discrepancies in some municipalities ${ }^{15}$.

There are no official and reliable data on the percentage of children from vulnerable groups (except Roma children) engaged in secondary education and their dropout rate.

According to RZS data (RZS-DevInfo, 2016) the rate of continuation of education after secondary school is $90.4 \%$.

\section{Conclusion}

The analysis of various dropout definitions and terms in use has shown interdependence between the conceptualisation of dropout and its measuring and monitoring. The differences between early school leaving and dropout were particularly stressed in this paper. Namely, in Europe and the USA different indicators are used for dropout and early school leaving monitoring. On the other hand, available statistical data in Serbia refer only to dropout. Consequently, there is no possibility for the systematic comparison with other countries. Still, the monitoring system of children enrolled in primary and secondary schools is not developed. Only descriptive data about a particular generation are available. This lack of basic data significantly hinders research, planning and prevention of school dropout in Serbia.

14 Boljevac, Srbobran, Rekovac, Nova Varoš and Barajevo.

15 More often, boys have a higher dropout rate (Barajevo, Batočina, Babušnica, Bač, Grocka, Boljevac, Bor, Ćuprija Despotovac, Kikinda, Osečina, Paraćin, Rekovac), and in several municipalities girls have a higher dropout rate (Crna Trava, Kladovo, Nova Varoš, Sokobanja, Srbobran, Svrljig). 
Dropout is a complex phenomenon influenced by various interconnected factors (De Witte et al., 2013; Janosz et al., 2000; Lamot et al., 2013; Lyche, 2010; Rumberger, 2011), which hampers the measuring of their impact. Hence, in this paper we adopted a common classification that includes individual, familial, school and systemic factors, without paying closer attention to solving the mentioned problem, but with the aim of presenting the findings of research studies around the world as well as those from Serbia. Regarding the Serbian research on dropout influences, we can conclude that there is no long tradition devoted to investigation. Hence, there are no systematic analyses and studies which rely on the previous data. Scientific interests in this topic in Serbia have mostly been related to the difficulties encountered by Roma students and the students with special needs.

According to available statistical data about the overall population of one generation of pupils, the results did not raise any concerns. The vast majority of children in Serbia enrol in (98\%) and complete (94\%) at least 8 years of schooling. Although secondary school in Serbia is not compulsory, the percentage of children who continue schooling after primary school at the national level is high, over $90 \%$. The gender gap, when observed, is not particularly big. However, the picture is not so optimistic when it comes to children from minority and vulnerable groups. In some municipalities, the coverage by primary education is between $70 \%$ and $80 \%$, and in some even below 70\%. Those municipalities are among the poorest and most socially and economically deprived municipalities in the country according to the List of municipalities' development for 2014 (Službeni glasnik Republike Srbije, 2014). The results of empirical studies on dropout in Serbia go in line with the assumption about the importance of socio-economic status of the family (Lazarević, Krstić \& Stepanović Ilić, 2014b; Simić \& Krstić, 2017; Videnović \& Lazarević, 2017). Along with an economically underprivileged situation, every fourth child whose mother did not finish primary school does not finish it as well (MICS 4, 2010). These results are in keeping with the Bourdieu's social reproduction framework where the role of the school system in intergenerational transmission of cultural capital is emphasised (e.g., Bordieu, 1977). Based on these data, a need for profound research of the obstacles the pupils from the poorest municipalities encounter is anticipated.

The data of particular concern are related to the dropout rate of children from Roma settlements. They have the lowest inclusion and completion rates for both primary and secondary school and the highest dropout rates. Less than $85 \%$ of children from Roma settlements are enrolled in primary education, and only $21 \%$ of them in secondary schools, with a significant gender discrepancy. There is plenty of empirical evidence on different kinds of difficulties they are confronted with, such as enrolment, school attendance, learning etc. (Baucal \& Stojanović, 2010). Still, more time and energy dedicated to this issue are necessary. 


\section{References}

Allensworth, E. M. (2005). Dropout rates after high-stakes testing in elementary school: A study of the contradictory effects of Chicago's efforts to end social promotion. Educational Evaluation and Policy Analysis, 27(4), 341-364.

Balfanz, R., Herzog, L. \& MacIver, D. (2007). Preventing Student Disengagement and Keeping Students on the Gradation Path in Urban Middle-Grades Schools: Early Identification and Effective Interventions. Educational Psychologist, 42(4), 223-235.

Battin-Pearson, S., Newcomb, M. D., Abbott, R. D., Hill, K. G., Catalano, R. F. \& Hawkins, J. D. (2000). Predictors of early high school dropout: A test of five theories. Journal of Educational Psychology, 92(3), 568-582.

Baucal, A. \& Stojanović, J. (2010). Indikatori jednake dostupnosti kvalitetnog obrazovanja za Rome. Beograd: Fond za otvoreno društvo. Retrieved from: https:// www.researchgate.net/publication/233820078_Jednaka_dostupnost_kvalitetnog_obrazovanja

Bertrand, A. L. (1962). School Attendance and Attainment: Function and Dysfunction of School and Family Social Systems. Social Forces 40(3), 228-33.

Blue, D., \& Cook, J. E. (2004). High school dropouts: Can we reverse the stagnation in school graduation? Study of High School Restructuring, 1(2), 1-11.

Bourdieu, P. (1977). Cultural Reproduction and Social Reproduction. In C. P. Bradshaw, J. Karabel \& A. H. Halsey (Eds.), Power and Ideology in Education (pp. 487- 511). New York: Oxford University Press.

Bowers, A. J. \& Sprott, R. (2012). Examining the Multiple Trajectories Associated with Dropping Out of High School: A Growth Mixture Model Analysis. The Journal of Educational Research, 105, 176-195.

O'Brennan, L. M., \& McNeely, C. A. (2008). Core competencies and the prevention of school failure and early school leaving. In N. G. Guerra \& C. P. Bradshaw (Eds.), Core competencies to prevent problem behaviours and promote positive youth development. New Directions for Child and Adolescent Development, 122, 19-32.

Bridgeland, J. M., Dilulio, J. J. \& Burke Morison, K. (2006). The silent epidemic: Perspectives of high school dropouts. Washington, DC: Civic Enterprises. Retrieved from: https://docs.gatesfoundation.org/Documents/TheSilentEpidemic3-06Final.pdf

Bynner, J. \& Parsons, S. (1997). It Doesn't Get Any Better; The Impact of Poor Basic Skill Attainment on the Lives of 37 Year Olds. London: The Basic Skills Agency. Retrieved from: http://shop.niace.org.uk/media/catalog/product/a/7/a729_it_ doesnt_get_any_better_english.pdf

Cairns, R. B., Cairns, B. D. \& Neckerman, H. J. (1989). Early school drop-out: Configurations and determinants. Child Development, 60, 1437-1452.

Cataldi, E. F., Laird, J., \& KewalRamani, A. (2009). High school dropout and completion rates in the United States: 2007 (NCES 2009-064). Washington, DC: National Center for Education Statistics, Institute of Education Sciences, US Department of Education. Retrieved from: http://nces.ed.gov/pubsearch/pubsinfo. asp?pubid=2009064

CEDEFOP, (2010). Skills Supply and Demand in Europe: Medium-Term Forecast up to 2020. Luxembourg: Publications Office of the European Union. Retrieved from: www.cedefop.europa.eu/files/3052_en.pdf 
Centar za obrazovne politike (COP), 2013. Obrazovna inkluzija dece romske nacionalnosti: Izveštaj o sprovedenom monitoringu u osnovnoškolskom obrazovanju. Retrieved from: http://www.cep.edu.rs/public/Obrazovna_inkluzija_dece_romske_nacionalnosti-1.pdf

Cooper, C. R., Chavira, G., \& Mena, D. (2005). From pipelines to partnerships: A synthesis of research on how diverse families, schools, and communities support children's pathways through school. Journal of Education for Students Placed at Risk, 10(4), 407-432.

Cvejić, S., Babović, M., Petrović, M., Bogdanov, N. i Vuković, O. (2010) Socijalna isključenost u ruralnim oblastima Srbije. Belgrade: UNDP Srbija, Sektor za inkluzivni razvoj. Retrieved from: https://secons.net/files/publications/38-Socijalna\%20isključenost\%20u\%20ruralnim\%20oblastima\%20Srbije.pdf

Čekić Marković, J., Radišić, J., Jovanović, V. \& Ranković, T. (2017). Developing a Model for Dropout Prevention and Intervention in Primary and Secondary Schools in Serbia: Assessing the Model Effectiveness. Psihološka istraživanja, 20(1), 145-169.

Dalton, B., Gennie, E., \& Ingels, S. J. (2009). Late high school dropouts: Characteristics, experiences, and changes across cohorts (NCES 2009-307). Washington, DC: National Center for Education Statistics, Institute of Education Sciences, US Department of Education. Retrieved from: http://nces.ed.gov/pubs2009/2009307.pdf

De Witte, K., Cabus, S., Thyssen, G., groot, W., \& van den Brink, H.M. (2013). A critical review of the literature on school dropout. Educational Research Review, 10, 13-28.

DesJardins, S., Ahlburg, D. A., \& McCall, B. (2006). The effects of interrupted enrolment on graduation from college: Racial, income, and ability differences. Economics of Education Review, 25(6), 575-590.

Dunn, C., Chambers, D. \& Rabren, K. (2004). Variables Affecting Students' Decisions to Drop Out of School. Remedial and Special Education 25(5), 314-323.

Dustmann, C., \& van Soest, A. (2008). Part-time work, school success and school leaving. Empirical Economics, 32, 277-299.

Entwisle, D. R., Alexander, K. L., \& Steffel-Olson, L. (2004). Temporary as compared to permanent high school dropout. Social Forces, 82(3), 1181-1205.

Estevao, P., \& Alvares, M. (2014). What do we mean by school dropout? Early school leaving and the shifting of paradigms in school dropout measurement. Portuguese Journal of Social Science, 13(1), 21-32.

EUROPE 2020 (2010). Communication from the Commission - Europe 2020: A strategy for smart, sustainable and inclusive growth. Brussels. Retrieved from: http://eur-lex.europa.eu/legal-content/EN/TXT/PDF/ uri=CELEX:52010DC2020\&from $=\mathrm{EN}$

European Commission/EACEA/Eurydice/Cedefop (2014). Tackling Early Leaving from Education and Training in Europe: Strategies, Policies and Measures. Eurydice and Cedefop Report. Luxembourg: Publications Office of the European Union. Retrieved from: http://eacea.ec.europa.eu/education/eurydice/documents/ thematic_reports/175EN.pdf

EUROSTAT (2005). Labor force survey. Retrieved from: http://ec.europa.eu/eurostat/ statistics-explained/index.php/Europe_2020_indicators_-_education 
Franceško, M., Mihić, V. \& Kajon, J. (2006). Social distance and stereotypes of Roma at the primary school age. Psihologija, 39(2), 167-182.

Garnier, H. E., Stein, J. A. \& Jacobs, J. K. (1997). The process of dropping out of high school: A 19-year perspective. American Educational Research Journal, 34, 395-419.

GHK (2005). Study on access to education and training, basic skills and early school leavers: final report; Brussels. Retrieved from: http://www.voced.edu.au/content/ngv\%3A33316

Hattie, J., (2009). Visible Learning: A Synthesis of over 800 Meta-analyses relating to achievement. London: Routledge.

Hawkins, J. D., Guo, J., Hill, K. G., Battin-Pearson, S., \& Abbott, R. D. (2001). Longterm effects of the social development intervention on school bonding trajectories. Applied Developmental Science, 5(4), 225-236.

Herbert, T. P., \& Reis, S. M. (1999). Culturally diverse high-achieving students in an urban high school. Urban Education, 34(4), 428-457.

Hidi, S. \& Harackiewicz, J. M. (2000). Motivating the academically unmotivated: A critical issue for the $21^{\text {st }}$ century. Review of Educational Research, 70(2), 151-179.

Ingrum, A. (2006). High School Dropout Determinants: The Effect of Poverty and Learning Disabilities. The Park Place Economist, 14(1). Retrieved from: http:// digitalcommons.iwu.edu/parkplace/vol14/iss1/16/

Janosz, M., Le Blanc, M., Boulerice, B., \& Tremblay, R. E. (1997). Disentangling the weight of school dropout predictors: A test on two longitudinal samples. Journal of Youth and Adolescence, 26(6), 733-762.

Janosz, M., Le Blanc, M., Boulerice, B. \& Tremblay, R. E. (2000). Predicting different types of school dropouts: A typological approach with two longitudinal samples. Journal of Educational Psychology, 92(1), 171-190.

Jimerson, S. R., Egeland, B., Sroufe, L. A., \& Carlson, B. (2000). A prospective longitudinal study of high school dropouts: Examining multiple predictors across development. Journal of School Psychology, 38(6), 525-549.

Kalmijn, M., \& Kraaykamp, G. (2003). Dropout and downward mobility in the educational career: An event-history analysis of ethnic schooling differences in the Netherlands. Educational Research and Evaluation, 9(3), 265-287.

Kaufman, P., Alt, M. N., \& Chapman, C. D. (2004). Dropout rates in the United States: 2001 (NCES 2005-046). Washington, DC: National Center for Education Statistics, US Department of Education. Retrieved from: https://nces.ed.gov/ pubs2005/2005046.pdf

Kovač Cerović, T., Jovanović, O. \& Pavlović Babić, D. (2016). Individual education plan as an agent of inclusiveness of the educational system in Serbia: Different perspectives, achievements and new dilemmas. Psihologija, 49(4), 431-445.

Krstić, K., Lazarević, L. \& Stepanović Ilić, I. (2016). Droput as a Result of Education with no Space for Diversity. In A. Surian (Ed.), Open Space for Interaction and Learning Diversities (pp.129-136). Rotterdam: Sense Publishers.

Lamb, A.S., Walstab, R. Teese, M. Vickers \&R. Rumberger (2004), Staying on at school: Improving student retention in Australia. Melbourne: Centre for Postcompulsory Education and Lifelong Learning, The University of Melbourne. Retrieved from: http://www.curriculum.edu.au/verve/_resources/studentretention_main_file.pdf 
Lamote, C., Speybroeck, S., Van Den Noortgate, W. \&Van Damme, J. (2013). Different pathways towards dropout: the role of engagement in early school leaving. Oxford Review of Education, 39(6), 739-760. Retrieved from: http://dx.doi.org/1 0.1080/03054985.2013.854202

Lazarević, Lj., Videnović, M. \& Stepanović Ilić, I. (2014a). Individual risk factors for dropout from school: Case study from Serbia. Paper presented at the ECER conference 2014: "The Past, the Present and Future of Educational Research in Europe" Porto, Portugal, September 1-5, 2014. Full paper retrieved from: http:// www.eera-ecer.de/ecer-programmes/conference/19/contribution/31152

Lazarević, Lj., Stepanović Ilić, I. \& Videnović, M. (2014b). Dropout: Analysis of family risk factors based on twelve case studies. Paper presented at the ECER conference 2014: "The Past, the Present and Future of Educational Research in Europe” Porto, Portugal, September 1-5, 2014. Full paper retrieved from: http:// www.eera-ecer.de/ecer-programmes/conference/19/contribution/31155

Legault, L., Green-Demers, I. \& Pelletier, L. (2006). Why Do High School Students Lack Motivation in the Classroom? Toward an Understanding of Academic Amotivation and the Role of Social Support. Journal of Educational Psychology, 98 (3), 567-582.

Lisbon, (2000). Lisbon European council 23 and 24 March 2000; Presidency conclusions. Retrieved from: http://www.europarl.europa.eu/summits/lis1_en.htm

Lyche, C. (2010). Taking on the Completion Challenge: A Literature Review on Policies to Prevent Dropout and Early School Leaving. OECD Education Working Papers, No. 53, OECD Publishing. Retrieved from: http://dx.doi. org $/ 10.1787 / 5 \mathrm{~km} 4 \mathrm{~m} 2 \mathrm{t} 59 \mathrm{cmr}-\mathrm{en}$

Mac Iver, D.J. \& Mac Iver, M. A. (2009). Beyond the Indicators: An Integrated School-level Approach to Dropout Prevention. Arlington, VA: The George Washington University Center for Equity and Excellence in Education. Retrieved from: http://files.eric.ed.gov/fulltext/ED539776.pdf

MICS4 (2010). Serbia Multiple Indicator Cluster Survey and Serbia Roma Settlements Multiple Indicator Cluster Survey, Final Reports. Belgrade: Republički zavod za statistiku \& UNICEF.

MICS5 (2014). Serbia Multiple Indicator Cluster Survey and Serbia Roma Settlements Multiple Indicator Cluster Survey, Final Reports. Belgrade: Republički zavod za statistiku \& UNICEF.

Milas, G., Ferić, I. \& Šakić, V. (2010). Osuđeni na socijalnu isključenost? Životni uvjeti i kvaliteta življenja mladih bez završene srednješkole. Društvena istraživanja, Zagreb, 19 (4-5), 669-689.

Ministry of Education, Science and Technological Development RS, Social Inclusion and Poverty Reduction Unit and UNICEF (2014). POLICY IMPACT ANALYSIS: Providing Additional Support to Students from Vulnerable Groups in Pre-University Education. Retrieved from: https://www.unicef.org/serbia/POLICY-IMPACT-ANALYSIS-Providing-Additional-Support-to-Students-fromVulnerable-Groups-in-Pre-University-Education.pdf

Nacionalni prosvetni savet (2011). Indikatori za praćenje stanja u obrazovanju $i$ vaspitanju. Nacionalni prosvetni savet, Beograd. Retrieved from: http://www.erisee. org/sites/default/files/Indicators\%20for\%20monitoring\%20of\%20education $\% 20$ 2011.pdf 
Nacionalni prosvetni savet (2012). Izveštaj o radu Nacionalnog prosvetnog saveta za 2012. godinu. Retrieved from: http://www.parlament.gov.rs/upload/archive/ files/lat/pdf/izvestaji/2013/1592\%20Izvestaj-\%20Nacionalni\%20prosvetni\%20 savet\%20R.S.\%20180413.pdf

Network of experts in social sciences of education and training (Nesse) (2010). Early School Leaving - Lessons from Research to Policy Makers. An independent expert report submitted to the European Commission. Retrieved from: https://www. spd.dcu.ie/site/edc/documents/nesse2010early-school-leaving-report.pdf

Newmann, F., Wehlage, C., \& Lamborn, S. (1992). The significance and sources of student engagement. In F.M. Newman (ed.), Student engagement and achievement in American secondary schools, (pp. 11-39). New York: Teachers College Press. Retrieved from: http://files.eric.ed.gov/fulltext/ED371047.pdf

Nield, R. C., Stoner-Eby, S. \& Furstenberg, F. (2008). Connecting Entrance and Departure: the Transition to Ninth Grade and High School Dropout. Education and Urban Society, 40(5), 543-569.

Open Society Institute (2010). Romska deca u „specijalnom” obrazovanju u Srbiji: prezastupljenost, niska postignuća i uticaj na život. Beograd: Fond za otvoreno društvo. Retrieved from https://www.cipcentar.org/preuzimanje/publikacije/ Romska\%20deca\%20u\%20specijalnom\%20obrazovanju\%20s\%20Srbiji.pdf

Orthner, D. K., Cook, P. G., Rose, R. A., \& Randolph, K. (2002). Welfare reform, poverty, and children's performance in school: Challenges for the school community. Children \& Schools, 24(2), 105-121.

Ou, S.R., \& Reynolds, A. J. (2006). Early childhood intervention and educational attainment: Age 22 findings from the Chicago longitudinal study. Journal of Education for Students Placed at Risk, 11(2), 175-198.

Pešikan, A. \& Ivić, I. (2016). The sources of inequity in the education system of Serbia and how to combat them. CEPS Journal, 6(2), 101-124.

Plank, S., DeLuca, S., \& Estacion A. (2005). Dropping out of high school and the place of career and technical education: a survival analysis of surviving high school. National Research Center for Career and Technical Education, S.P.M.N. \& National Dissemination Center for Career and Technical Education,C.O.H. Retrieved from: http://www.nrccte.org/sites/default/files/publication-files/droppingout-plank.pdf

Rado, P. (2010). School Failure in Serbia. Psihološka istraživanja, 13(1), 59-90.

Rajović. V. (2008). Problemi kompetentnosti nastavnika za inkluzivno obrazovanje - ka evropskom kontekstu razvijanja kompetencija nastavnika za inkluzivno obrazovanje. In Š. Alibabić \& A. Pejatović, (Eds.) Obrazovanje i učenje - pretpostavke evropskih integracija (pp. 245-258). Beograd: Institut za pedagogiju i andragogiju.

Republički zavod za statistiku, (2012). Statistički godišnjak Republike Srbije - Obrazovanje. Beograd: RZS. Retrieved from: http://pod2.stat.gov.rs/ObjavljenePublikacije/G2012/pdf/G20122007.pdf

Republički zavod za statistiku (RZS) (2015a). Obrazovanje. In: Statistički godišnjak Republike Srbije. Beograd: RZS. Retrieved from: http://webrzs.stat.gov.rs/WebSite/repository/documents/00/01/91/96/05_Obrazovanje.pdf

Republički zavod za statistiku (RZS) (2015b), Srednjoškolsko obrazovanje u Srbiji. In: Bilten 595 za 2015.god. Retrieved from: http://webrzs.stat.gov.rs/WebSite/repository/documents/00/01/74/98/SB-595-Srednj_obrazov_2014-2015.pdf 
Rumberger, R. \& Lim, S. (2008). Why Students Drop Out of School: A Review of 25 Years of Research. California Dropout Research Project, Santa Barbara. Retrieved from: http://www.slocounty.ca.gov/Assets/CSN/PDF/Flyer++Why+students+drop+out.pdf

Rumberger, R. W. (1983). Dropping out of high school: The influence of race, sex, and family background. American Educational Research Journal, 20(2), 199-220.

Rumberger, R. W. (1987). High school dropouts: A review of issues and evidence. Review of Educational Research, 57, 101-121.

Rumberger, R. W. (2004). Why students drop out of school? In G. Orfied (Ed.), Dropouts in America: Confronting the graduation rate crisis (pp. 131-155). Cambridge MA: Harvard Education Press.

Rumberger, R. W. (2011). Dropping out: Why students drop out of high school and what can be done about it. Cambridge, Mass.: Harvard University Press. Retrieved from: http://mina.education.ucsb.edu/rumberger/book/ch1.pdf

RZS-DevInfo (2016). Online database retrieved from: http://devinfo.stat.gov.rs/ DI6Web/home.aspx

Serbian Government (2011). Prvi nacionalni izveštaj o socijalnom uključivanju $i$ smanjenju siromaštva. Retrieved from: http://www.inkluzija.gov.rs/wp-content/ uploads/2011/03/Prvi-nacionalni-izvestaj-o-socijalnom-ukljucivanju-i-smanjenju-siromastva1.pdf

Službeni glasnik Republike Srbije (2012). Razvoj obrazovanja u Srbiji do 2020. godine. No. 107. Retrieved from: http://www.scnis.rs/files/Закони/Strategija_razvoja_obrazovanja.pdf

Službeni glasnik Republike Srbije (2014). Jedinstvena lista razvijenosti regiona i jedinica lokalne samouprave za 2014. godinu. No. 104. Retrieved from: http://ras. gov.rs/uploads/2017/03/podrska\%20za\%20otvaranje\%20novih\%20radnih\%20 mesta/Lista\%20razvijenosti\%20JLS.pdf

Simić, N. \& Krstić, K. (2017). School factors from primary and secondary education in Serbia - qualitative research. Psihološka istraživanja, 20(1), 51-70.

Stepanović Ilić, I., Lazarević, L. \& Simić, N. (2017). Social factors outside of family and school related to student dropout. Psihološka istraživanja, 20(1), 89-105.

Strategija razvoja obrazovanja u Srbiji do 2020. godine (2012). Službeni glasnik RS. Br. 107.

Suh, S., Suh, J. \& Houston, I. (2007). Predictors of categorical at-risk high school dropouts. Journal of Counseling and Development, 85, 196-203.

Tim za socijalno uključivanje i smanjenje siromaštva i RZS (2012). Praćenje socijalne uključenosti u Srbiji. Retrieved from: http://www.minrzs.gov.rs/files/doc/porodi$\mathrm{ca} /$ strategije/Pracenje-stanja-socijalne-iskljucenosti-Avg-2012.pdf

Traag, T. \& R. van der Velden (2008), Early School Leaving in the Netherlands, the Role of Student-,Family-, and School Factors for Early School-leaving in Lower Secondary Education. Maastricht: Research Centre for Education and the Labour Market. Retrieved from: https://www.cbs.nl/NR/rdonlyres/CAFDC1FC-E23B49C8-9833-2AE9E639E4E3/0/2012X11Traagpub.pdf

UNESCO (1997). International Standard Classification of Education. Retrieved from: http://www.unesco.org/education/information/nfsunesco/doc/isced_1997.htm 
UNICEF, IPSOS, \& Ministarstvo prosvete, nauke i tehnološkog razvoja RS (2015). Analiza kvaliteta obrazovanja u školama i odeljenjima za obrazovanje dece sa posebnim potrebama. The report on social inclusion. Retrieved from: http://socijalnoukljucivanje.gov.rs/wp-content/uploads/2016/06/analiza_kvaliteta_obrazovanja_u_skolama_i_odeljenjima_za_obrazovanje_dece_sa_ smetnjama_u_razvoju.pdf

Videnović, M \& Lazarević, Lj. (2017). Familial and individual reasons for student dropout: Students' perception. Psihološka istraživanja, 20(1), 71-88.

Wang, M.T. \& Fredricks, J.A. (2014).The Reciprocal Links Between School Engagement, Youth Problem Behaviors, and School Dropout During Adolescence. Child Development, 85 (2), 722-737.

\title{
Odustajanje od u školovanja u osnovnom i srednjem obrazovanju u Republici Srbiji
}

\section{Ksenija Krstić}

Univerzitet u Beogradu, Filozofski fakultet

\section{Ivana Stepanović Ilić}

Univerzitet u Beogradu, Filozofski fakultet, Insrtitut za psihologiju

\section{Marina Videnović}

Univerzitet u Beogradu, Filozofski fakultet, Insrtitut za psihologiju

\begin{abstract}
Napuštanje obrazovanja je veoma ozbiljan problem u čitavom svetu. U ovom radu su razmatrane različite definicije osipanja i konsekvence tih određenja na merenje i praćenje napuštanja škole od strane dece u Srbiji u kontekstu poređenja sa razvijenim zapadnim zemljama. Na osnovu pregelda relevantne literature se može zaključiti da brojni različiti faktori utiču na osipanje (individualni, porodični, školski i širi socijalni faktori povezani sa obrazovnim sistemom kao celinom i karakteristikama regiona). Imajući to u vidu, ovde smo pokušali da sumiramo razmatranja o tim faktorima i pružimo informacije o studijama koje se bave njihovim istraživanjem u Srbiji. Uzimajući u obzir činjenicu da u Srbiji nema sistematske analize stope osipanja iz osnovnog i srednjeg obrazovanja, prezentovani su postojeći statistički podaci o tom problemu iz različitih izvora. Jedan od najvažnijih zaključaka ove studije tiče se neophodnosti razvijanja daljeg naučnog inetersa i povećanja broja studija o osipanju kako bi se došlo do primenjivih strategija za praćenje, prevenciju i uspešnu interevnciju.
\end{abstract}

Ključne reči: osipanje, definicije, praćenje, uzroci i postojeće statistike o stopi osipanja u Srbiji 